\title{
Frequency of CCR5 Promoter Polymorphism Affecting the Rate of Progression to AIDS (59029-G/A) in Kuwaitis
}

\author{
Mariam Al-Turab Alexander Voevodin \\ Department of Microbiology, Faculty of Medicine, Kuwait University, Kuwait
}

\section{Key Words}

Human immunodeficiency virus type I - CCR5 . 59029 G/A · Polymerase chain reaction - Genetic resistance Allele frequency

\begin{abstract}
Objective: To estimate the frequencies of 59029-G and 59029-A alleles associated with slow and rapid progression to AIDS in Kuwaitis. Methods: The DNA was extracted from 109 blood samples of healthy unrelated Kuwaitis. The 59029-G/A polymorphism was detected by the polymerase chain reaction/restriction fragment length polymorphism (PCR-RFLP) test. The amplification of a 268-bp fragment of the CCR5 gene encompassing the site of the polymorphism was followed by digestion with restriction endonuclease $B s p$ 1286l and sizing the DNA fragments by agarose gel electrophoresis. Results: Among 109 individuals genotyped, 10, 44 and 55 were 59029-A/A homozygous, 59029-G/G homozygous and 59029-G/A heterozygous, respectively. The frequency of the $\mathrm{G}$ allele was 0.66 (95\% Cl: $0.59-0.72)$ while the frequency of the A allele was 0.34 (95\% Cl: 0.28-0.41). Conclusions: The frequency of the AIDS-'protective' 59029-G allele in Kuwaitis is significantly higher than the frequency of the 'rapid-progression' 59029-A allele. Moreover, the frequency of the 59029-G allele in Kuwaitis is among the highest reported. However, the difference from the 59029-G allele frequencies of other ethnic groups in some cases is not statistically significant.
\end{abstract}

Copyright $@ 2001$ S. Karger AG, Basel

\begin{tabular}{ll}
\hline KARGER & ( ) 2001 S. Karger AG, Basel \\
1011-7571/01/0101-0002\$17.50/0 \\
$\begin{array}{l}\text { Fax +4161306 1234 } \\
\begin{array}{l}\text { E-Mail karger@karger.ch } \\
\text { www.karger.com }\end{array}\end{array}$ & $\begin{array}{l}\text { Accessible online at: } \\
\text { www.karger.com/journals/mpp }\end{array}$
\end{tabular}

\section{Introduction}

The rate of progression of human immunodeficiency virus (HIV) infection to AIDS varies among individuals. Most HIV-infected individuals develop AIDS within 10 years of infection, but approximately $5 \%$ of HIV-positive subjects remain clinically and immunologically stable for 10-15 years or apparently do not progress to AIDS at all. Such individuals are referred to as 'slow progressors' or 'long-term non-progressors'. On the other hand, there is a group referred to as 'exposed uninfected' individuals those who are repeatedly exposed to HIV but remain uninfected [1-3].

Factors accounting for long-term non-progression may include infection with an attenuated strain of HIV, genetic polymorphisms in the host and stronger than usual virus-specific immune responses [4]. There is strong evidence for such a role for host genetic factors. Most of the genetic polymorphisms conferring resistance against HIV infection and/or delayed progression to AIDS are located in the genes encoding some of the chemokine receptors and chemokines. The most important among them are CCR5 432 [5, 6], CCR5 59029 G/A [7], CCR2-64I [8, 9] and SDF1-3'A [10].

The CCR5 $\Delta 32$ mutation is a 32-base-pair (bp) deletion in the open reading frame of the CCR5 gene. The CCR5 gene containing $\Delta 32$ encodes the non-functional HIV-1 co-receptor [5]. As a result CCR5 $\Delta 32$ homozygotes are completely protected against HIV-1 infection with M-tropic strains [11], while in HIV-1-positive CCR5

Dr. Alexander Voevodin

Department of Microbiology, Faculty of Medicine

Health Sciences Center, Kuwait University

PO Box 24923, Safat 13110 (Kuwait)

Tel./Fax +965 5735201, E-Mail voevodin@hsc.kuniv.edu.kw 
$\Delta 32$ heterozygotes the progression to AIDS is delayed on average for 2 years $[5,6]$. CCR $5 \Delta 32$ is quite common in Caucasians and found at lower frequencies in the Middle East, but it is very rare among native Africans, Amerindians and East Asians $[5,6,11,12]$. The allele frequency in Caucasians is about $10 \%$, and approximately $1 \%$ of this population is homozygous. In Kuwaitis the allele frequency of CCR $5 \Delta 32$ is approximately $1 \%$, and about $2 \%$ of Kuwaitis are heterozygous for the mutation [13].

The CCR2-64I is a single nucleotide polymorphism leading to a conservative amino acid substitution - valine to isoleucine at position 64 in the first transmembrane domain of CCR2. This allele is associated with delayed progression to AIDS by 2-3 years in both heterozygous and homozygous subjects $[8,9,14]$. The CCR2-64I mechanism of protection is not known. It has been suggested that CCR2-64I may be linked to another polymorphism that affects CCR5 expression [8, 15]. The differential dimer interaction of CCR2-64I and wild-type CCR2 with CCR5 peptides inside T cells may also affect the availability of CCR5 for HIV [16]. The CCR2-64I allele is found in all racial groups in the USA with the following frequencies: Caucasians $=10 \%$, Afro-Americans $=15 \%$, Hispanics $=17 \%$, Asians $=25 \%[8]$. The allele frequency of CCR2-64I in Kuwaitis is 12\% [17].

The SDF1-3' A polymorphism is $\mathrm{G} \rightarrow$ A substitution at position 809 in the $3^{\prime}$-untranslated region of the gene encoding for the stromal derived factor 1 (SDF1), the ligand for chemokine receptor CXCR4 [10]. The latter is a co-receptor for T-tropic (X4-tropic) strains of HIV. The protective effect of the SDF1-3'A allele is recessive. Thus, it is observed only in SDF1-3'A homozygotes. The possible mechanism of action could involve increased SDF1 leading to blockade of CXCR4 [7, 10]. The SDF1-3'A allele is found in all racial groups in the USA with the following frequencies: Caucasians $=21 \%$, Hispanics $=$ $16 \%$, Asians $=26 \%$, Afro-Americans $=6 \%$ [10]. The allele frequency of SDF1-3'A in Kuwaitis is $26 \%$, and approximately $6 \%$ of Kuwaitis are SDF1-3'A homozygous [17].

The most recently identified polymorphism in the chemokine receptor genes affecting the rate of progression to AIDS is referred to as CCR5 59029-G/A. It is a single nucleotide polymorphism, G versus A at position 59029 in the CCR5 promoter region [7]. Both 59029-G and 59029-A alleles are quite common in all racial groups tested (in the USA). The allele frequencies of 59029-A are Caucasians $=57 \%$, Afro-Americans $=43 \%$, Asians $=47 \%$ and Hispanics $=68 \%$ [7]. The frequencies of 59029-G and 59029-A alleles in Arabs were not known.
Table 1. The size of the bands (bp) characteristic of different genotypes

\begin{tabular}{llll}
\hline Mutation & \multicolumn{3}{l}{ Genotype } \\
\cline { 2 - 4 } & A/A & A/G & G/G \\
\hline 59029-G/A & 268 & 268,130 & 130 \\
\hline
\end{tabular}

The 59029-G allele is associated with slower progression to AIDS - about 4 years delay in 59029-G homozygotes as compared with 59029-A homozygotes. In heterozygotes (59029-G/A genotype) the rate of progression to AIDS appears to be intermediate [7]. The mechanism of protection may be related to reduction in CCR 5 mRNA production in the presence of the 59029-G allele [7]. It is of importance that the protective effect of $59029-\mathrm{G}$ in homozygotes is twice as strong as those of the CCR $5 \Delta 32$ or CCR2-64I alleles and is independent of protection conferred by other variants [7].

This study was aimed at an estimation of the frequencies of 59029-G and 59029-A alleles in Kuwaitis.

\section{Materials and Methods}

\section{DNA Samples}

Blood specimens were collected from 109 healthy unrelated Kuwaitis. The DNA was extracted from leucocytes using the 'salting out' method [18].

\section{Genotyping for 59029-G/A Polymorphism}

The polymorphisms were determined according to McDermott et al. [7] using polymerase chain reaction (PCR) followed by restriction fragment length polymorphism (RFLP). The primers 59029-S (5'-CCCGTGCCCATAGTTAAAACTC-3') and 59029-AS (5'-TCACAGGGCTTTTCAACAGTAAGG-3') were used for amplification of the 268-bp fragment of the CCR5 gene encompassing the site of the 59029-G/A polymorphism. The reaction mixture included standard PCR buffer (10 mM Tris- $\mathrm{mCl}, \mathrm{pH} 8.3,50 \mathrm{~m} M \mathrm{KCl}, 1.5 \mathrm{~m} M$ $\mathrm{MgCl}_{2}$ ), $50 \mu M$ of each of deoxynucleoside triphosphates, $10 \mathrm{pmol}$ of each primer, 0.75 unit of AmpliTaq Gold DNA polymerase and approximately $500 \mathrm{ng}$ of genomic DNA in a total volume of $25 \mu 1$. Thermocycling $\left(10 \mathrm{~min}\right.$ at $94^{\circ} \mathrm{C}$, then 30 cycles at $94^{\circ} \mathrm{C}, 55^{\circ} \mathrm{C}$ and $72^{\circ} \mathrm{C}, 30 \mathrm{~s}$ at each temperature) was performed in a Perkin-Elmer System 9600. After amplification by PCR the product was digested by the restriction endonuclease $B s p 1286 \mathrm{I}$ [recognition/cutting sites: $\left.5^{\prime}-\mathrm{G}(\mathrm{G} / \mathrm{A} / \mathrm{T}) \mathrm{GC}(\mathrm{C} / \mathrm{A} / \mathrm{T}) \downarrow \mathrm{C}-3^{\prime} / / 3^{\prime} \mathrm{C} \downarrow(\mathrm{C} / \mathrm{T} / \mathrm{A}) \mathrm{CG}(\mathrm{G} / \mathrm{T} / \mathrm{A}) \mathrm{G}-5^{\prime}\right]$. The fragments obtained after digestion were sized by agarose gel (1.4\%) electrophoresis. The sizes of the bands characteristic of different genotypes are presented in table 1 . 


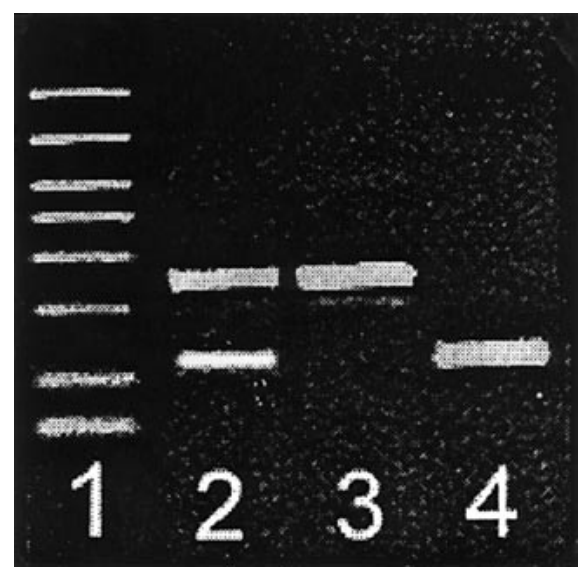

Fig. 1. Typical result of PCR-RFLP genotyping. Lane 1: fragment size markers $(50,100,200,300,400,500,700$ and 1,000 bp); lane 2: 59029 G/A genotype (130-bp and 268-bp bands); lane 3: 59029 A/A genotype (268-bp band); lane 4: 59029 G/G genotype (130-bp band).

Computation of Confidence Intervals for Allele Frequencies

Computation of $95 \%$ confidence intervals for allele frequencies was done using the option 'confidence interval for proportions' of the program StatMate Version 1.0 (GraphPad Software Inc., San Diego, Calif., USA).

\section{Results and Discussion}

Among the 109 individuals genotyped for the 59029G/A polymorphism, 10, 44 and 55 were identified as 59029-A/A homozygous, 59029-G/G homozygous and 59029-G/A heterozygous, respectively. The frequency of the $\mathrm{G}$ allele was 0.66 (95\% CI: 0.59-0.72) while the frequency of the A allele was 0.34 (95\% CI: 0.28-0.41). The typical result of PCR-RFLP genotyping is shown in figure 1.
The frequency of the 59029-G allele in Kuwaitis is significantly higher than the frequency of the 59029-A allele. Moreover, the frequency of the protective allele (59029-G) in Kuwaitis is among the highest reported. At the same time, the difference from the 59029-G allele frequencies in other ethnic groups in some cases is not statistically significant. The nature of selective factors contributing to such an extensive accumulation of the 59029-G allele in Arabs, represented by Kuwaitis, remains unknown. The most plausible possibility is selective advantage provided by the 59029-G allele with respect to resistance to infectious diseases that might have had a great impact on the survival of ancient Middle Eastern populations. In this framework, a potential link between CCR5 59029-G/A genotypes and susceptibility/resistance to such diseases as plague and smallpox has to be explored.

\section{Conclusion}

This study provided the first data on the frequency of 59029-G/A polymorphisms in Arabs. Genotyping HIVpositive Kuwaitis for these polymorphisms as well as a prospective study of their impact on the pace of progression to AIDS in Arabs is currently in progress. The preliminary results of this study show that the frequencies of 59029-G and 59029-A alleles in HIV-positive Kuwaitis are not significantly different from those in healthy $\mathrm{Ku}-$ waitis.

\section{Acknowledgment}

This work was supported by an MSc Research Project Grant from the College of Graduate Studies and Research Grant MI 120 from the Research Administration, Kuwait University.

\section{References}

1 Berger EA, Murphy PM, Farber JM: Chemokine receptors as HIV-1 coreceptors: Roles in viral entry, tropism and disease. Annu Rev Immunol 1999; 17:657-700.

2 Rowland-Jones SL: Long term non-progression in HIV infection: Clinicopathological issues. $\mathrm{J}$ Infect 1999;38:67-70.
3 Easterbrook PJ, Rostron T, Ives N, Troop M, Gazzard BG, Rowland-Jones SL: Chemokine receptor polymorphisms and human immunodeficiency virus disease progression. J Infect Dis 1999;180:1096-1105.

4 Alexander L, Weiskopf E, Greenough TC, Gaddis NC, Auerbach MR, Malim MH, O'Brien SJ, Walker BD, Sullivan JL, Desrosiers RC: Unusual polymorphisms in human immunodeficiency virus type 1 associated with non-progressive infection. J Virol 2000;74: 4361-4376.
5 Dean M, Carrington M, Winkler C, et al: Genetic restriction of HIV-1 infection and progression to AIDS by a deletion allele of the CKR5 structural gene. Hemophilia Growth and Development Study, Multicenter AIDS Cohort Study, Multicenter Hemophilia Cohort Study, San Francisco City Cohort, ALIVE Study. Science 1996;273:1856-1862. 
6 Huang Y, Paxton WA, Wolinsky SM, et al: The role of a mutant CCR5 allele in HIV-1 transmission and disease progression. Nat Med 1996;2:1240-1243.

7 McDermott DH, Zimmerman PA, Guignard F, Kleeberger CA, Leitman SF, Murphy PM: CCR 5 promoter polymorphism and HIV-1 disease progression. Lancet 1998;352:866-870.

8 Smith MW, Dean M, Carrington M, Winkler $\mathrm{C}$, et al: Contrasting genetic influence of CCR2 and CCR5 variants on HIV-1 infection and disease progression. Hemophilia Growth and Development Study (HGDS), Multicenter AIDS Cohort Study (MACS), Multicenter Hemophilia Cohort Study (MHCS), San Francisco City Cohort (SFCC), ALIVE Study. Science 1997;277:959-964.

9 Kostrikis LG, Huang Y, Moore JP, Wolinsky SM, Zhang LQ, Guo Y, Deutsch L, Phair J, Neumann AU, Ho DD: A chemokine receptor CCR2 allele is associated with a CCR 5 promoter mutation. Nat Med 1998;4:350-353.
10 Winkler C, Modi W, Smith MW, et al: Genetic restriction of AIDS pathogenesis by an SDF1 chemokine gene variant. ALIVE Study, Hemophilia Growth and Development Study (HGDS), Multicenter Hemophilia Cohort Study (MHCS), San Francisco City Cohort (SFCC). Science 1998;279:389-393.

11 Lui R, Paxton WA, Choe S, et al: Homozygous defect in HIV-1 coreceptor accounts for resistance of some multiply exposed individuals to HIV-1 infection. Cell 1996;86:367-377.

12 Martinson JJ, Chapman NH, Rees DC, Liu YT, Clegg JB: Global distribution of the CCR5 gene 32-base pair deletion. Nat Genet 1997;16: 100-103.

13 Voevodin A, Samilchuck E, Dashti S: A survey for 32 nucleotide deletion in the CCR 5 chemokine receptor gene $(\Delta c c r-5)$ conferring resistance to human immunodeficiency virus type 1 in different ethnic groups and in chimpanzees. J Med Virol 1998;55:147-151.
14 Rizzardi GP, Morawetz RA, Vicenzi E, Chezzi S, Poli G, Lazzarin A, Pautaleo G: CCR2 polymorphism and HIV disease. Nat Med 1998;4: 252-253.

15 Lee B, Doranz BJ, Doms RW: Influence of the CCR2-V 64I polymorphism on human immunodeficiency virus type 1 coreceptor activity and on chemokine receptor function of CCR2b, CCR3, CCR5 and CXCR4. J Virol 1998;72:2509-2515.

16 Mellado M, Rodriguez-Frade J, Vila-Coro A, Ana A, Martinez AC: Chemokine control of HIV-1 infection. Nature 1999;400:723-724.

17 Voevodin A, Samilchuck E, Dashti S: Frequency of SDF-1 chemokine, CCR-5 and CCR-2 chemokine receptor gene alleles conferring resistance to human immunodeficiency virus type 1 and AIDSA in Kuwaitis. J Med Virol 1999;58:54-58.

18 Miller S, Dykes D, Polesky H: A simple salting out procedure for extracting DNA from human nucleated cells. Nucleic Acids Res 1988;16: 1215 